\title{
PELATIHAN BERBICARA DI DEPAN UMUM BAGI SISWA SEKOLAH KRISTEN PNIEL, NAMO RAMBE DELI SERDANG, SUMATERA UTARA
}

\author{
Agustin Diana Wardaningsih \\ ${ }^{1}$ Universitas Pelita Harapan \\ agustin.wardaningsih@uph.edu
}

\begin{abstract}
Abstrak
Manusia diciptakan Tuhan dengan kesempurnaan, salah satunya diberikan indera untuk berbicara. Manusia berbicara untuk mengeluarkan pikiran dan perasaan. Pelatihan dasar berbicara di depan publik merupakan sebuah cara untuk mengembangkan ketrampilan berbicara agar kita bisa menyampaikan ide yang ada di pikiran kita, membagikan apa yang kita rasakan, sehingga bisa menjadi pengalaman yang bisa membantu orang lain juga untuk berkembang. Tujuan Kegiatan untuk melatih percaya diri, menjadi pendengar yang baik, dan menghargai orang lain. Dengan peserta adalah siswa SMP dan SMA Sekolah Kristen Pniel, Namo Rambe Deli Serdang, Sumatera Utara. Kegiatan berlangsung secara virtual selama 120 menit pada 07 Mei 2021, untuk membantu siswa bisa berbicara secara terstruktur, dan efektif sehingga juga lebih percaya diri dan mengembangkan kemampuan lebih baik. Kegiatan walau dilakukan secara virtual telah berjalan dengan baik, dan antusias siswa untuk mau mencoba berlatih juga cukup tinggi. Kegiatan ini berhasil memberikan pembelajaran baru bagi siswa terutama di masa Covid 19 ini untuk tetap bisa mengembangkan diri dan melatih kepercayaan diri.
\end{abstract}

Kata Kunci : Komunikasi, Komunikasi Publik, Komunikasi Interpersonal, Pengembangan Diri.

\section{PENDAHULUAN}

Komunikasi menjadi bagian mendasar dalam kehidupan kita baik secara pribadi, dalam lingkup sosial di masyarakat, ataupun secara professional di tempat kerja. Kemampuan berkomunikasi menjadi bagian penting yang harus dikuasai, karena terkadang ada sejumlah keputusan yang perlu dibuat lewat proses komunikasi. Bahkan untuk berinteraksi dengan situasi dan orang lain, kita menggunakan komunikasi sebagai salah satu cara menentukan cara bertindak dan berhubungan dengan orang lain. Definisi komunikasi menurut West dan Turner (2017, p5) adalah "Communication is a social process in which individuals employ symbols to establish and interpret meaning in their environment". Sebagai proses sosial maka komunikasi berlangsung terus menerus dalam masyarakat, dan setiap interaksi akan menciptakan makna dari simbol-simbol pada lingkungan tertentu. Griffin (2012, p.6) juga memberikan definisi terkait dengan komunikasi yaitu sebagai: "Communication is the relational process of creating and interpreting messages that elicit a response". Yang dapat dipahami bahwa komunikasi adalah proses relasional dalam menciptakan dan menginterpertasikan pesan dimana dalam proses tersebut akan Pendidikan 690 
menghasilkan respon. Makna dapat diciptakan lewat interaksi antar manusia, manusia di dalam sebuah organisasi, bahkan interaksi antar manusia dengan khalayak banyak.

Dalam sejarah Indonesia, salah satu tokoh yang memiliki kemampuan berbicara pada khalayak adalah presiden Indonesia pertama yaitu Ir. Soekarno. Beliau sanggup berpidato dengan muatan pesan yang sangat kuat karena penuh dengan nilai-nilai positif bagi yang mendengar pidatonya. Kemampuan berbicara di depan umum yang dimiliki oleh bapak Soekarno merupakan sebuah bakat dan kemampuan untuk berbicara di depan umum (Gani, Astuti, Kusumalestari, 2020, h. 10). Salah satu pesan Soekarno bagi anak muda bangsa Indonesia masa itu adalah "gantungkan cita-citamu setinggi langit, bermimpilah setinggi karena jika engkau jatuh maka akan jatuh diantara bintangbintang”. Pesan ini memberikan semangat bagi anak muda di saat itu, bahkan juga untuk masa kini. Bagi generasi muda saat ini, ada salah satu figur publik yang juga mampu memberikan pesan yang kuat pada saat berbicara di depan umum. Boyband Bangtan Boys alias BTS asal Korea Selatan berhasil membuat sejarah dengan tampil berpidato di depan Majelis Umum Perserikatan Bangsa-bangsa (PBB) atas undangan dari Organisasi PBB untuk perlindungan anak (UNICEF) pada 24 September 2018(CNN Indonesia, 2018). Pidato tersebut diberikan sebagai salah satu rangkaian kerjasama antara UNICEF dan BTS dalam tour "Love My self" yang diselenggarakan tahun sebelumnya. Hanya dengan berpidato selama kurang lebih tujuh menit, dan salah satu pesan yang mengakhiri pidato yang disampaikan leader BTS Kim Nam Joon (RM) dalam dokumentasi tayangan yang bisa dilihat di Youtube.com (2018) yaitu "No matter who you are, where you're from, your skin colour, gender identity, speak yourself". Dengan hanya pidato singkat tersebut, memiliki kekuatan persuasi yang sangat tinggi bagi anak muda untuk berani berbicara dan menyampaikan pendapat.

Berbicara dan menyampaikan pendapat apalagi di hadapan publik bukan sesuatu yang mudah. Tidak semua orang memiliki bakat dan kemampuan untuk bisa berbicara di depan publik, apapun profesi kita, kedudukan, dan bahkan usia. Untuk anak muda yang masih duduk di bangku sekolah SMP atau SMA, juga membutuhkan kemampuan untuk berani berbicara di depan umum, dari yang paling sederhana untuk berani menyampaikan pendapat saat ditanya guru di sekolah atau menyampaikan presentasi di depan kelas. Tidak percaya diri merupakan salah satu alasan utama yang terkadang membuat siswa sekolah enggan untuk berbicara di depan umum saat kegiatan di sekolah. Sehingga hal ini perlu untuk dilatih karena kemampuan berbicara di depan umum merupakan hal yang penting dipelajari. Bukan saja untuk sekedar melatih percaya diri tetapi juga untuk mengembangkan potensi diri, membuat struktur pembicaraan sehingga bisa memberikan informasi atau pesan kepada khalayak dengan lebih baik. Inilah salah satu tujuan dari penyelenggaraan pengabdian kepada masyarakat (PKM) pelatihan berbicara di depan umum bagi siswa SMP dan SMA di Yayasan Pniel , Namo Rambe, Deli Serdang, Sumatera Utara.

Dari survey awal melalui komunikasi lewat media online, terungkap fakta dari pihak sekolah adanya kesulitan untuk meminta anak berani berbicara dengan aktif di kelas bertanya pada guru, atau maju ke depan kelas untuk presentasi. Profil siswa cenderung pasif, sehingga kadang kelas hanya diisi penyampaian materi guru, sementara metode pembelajaran guru sudah berusaha untuk membuat siswa aktif di kelas dengan berdiskusi dan interaksi berbicara 
dengan sesama teman di kelas. Pasifnya kelas makin terasa saat pandemi Covid 19 merebak. Keterbatasan fasilitas dan kemampuan ekonomi siswa tidak memungkinkan untuk melakukan pembelajaran secara online, sehingga pihak sekolah memutuskan untuk membagi waktu sekolah siswa agar mengurangi kepadatan kelas dan interaksi agar menghambat penyebaran virus Covid 19. Situasi ini membuat kondisi kelas makin sepi karena jumlah anak tidak banyak, anak menjadi kehilangan semangat untuk belajar, dan sulit untuk menyerap materi pelajaran yang membuat prestasi akademik sebagian besar anak menurun. Dari permintaan pihak sekolah dan diskusi bersama maka diputuskan untuk menyelenggarakan pelatihan berbicara di depan umum bagi siswa SMP dan SMA. Sehingga tujuan pelatihan bukan hanya meningkatkan kepercayaan diri, tetapi sebagai usaha untuk mengembangkan diri terutama dengan ketrampilan berbicara di depan umum secara efektif, mampu menjadi pendengar yang baik, dan mampu berbicara secara terstruktur sehingga pesan yang akan disampaikan bisa diterima dengan baik bagi penerima pesan tersebut.

\section{METODE}

Kegiatan pengabdian kepada masyarakat lewat pelatihan berbicara di depan umum dilakukan secara virtual lewat zoom meeting dengan durasi waktu 120 menit ( 2 jam) pada 07 Mei 2021. Metode pembelajarannya adalah dengan pemberian materi dan praktek, dengan mekanismenya adalah peserta sejumlah kurang lebih 60 siswa, dengan didampingi guru-guru disatukan dalam sebuah ruangan aula yang cukup besar, dengan protokol kesehatan penggunaan masker dan duduk berjarak. Ada layar besar yang memudahkan anak untuk menyerap informasi dan materi walaupun dilakukan secara online. Pada sesi pertama selama kurang lebih 40 menit, disampaikan pemaparan materi, untuk kemudian sisa waktu yang ada digunakan untuk praktek.

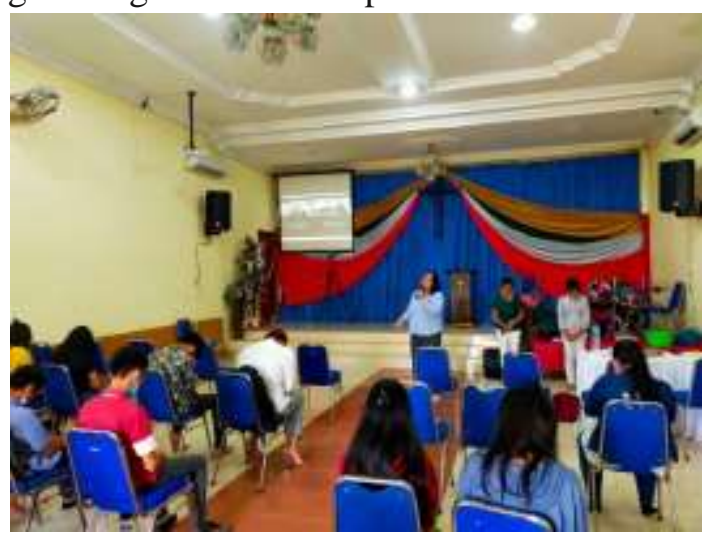

Gambar 1 : Sesi pembukaan

Sumber : Dokumentasi Sekolah

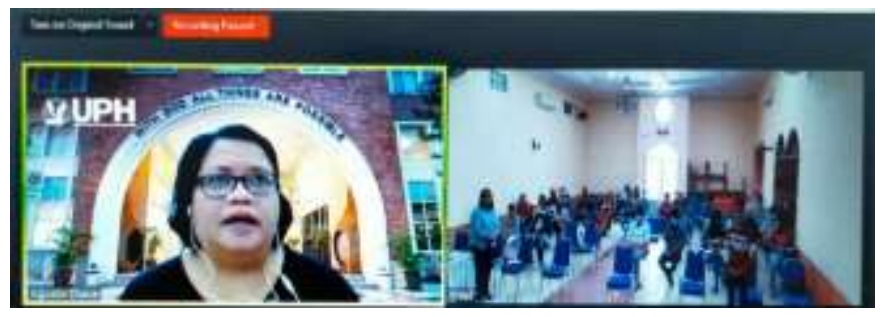

Gambar 2 : Sesi Materi

Sumber : Dokumentasi Sekolah

Salah satu metode berbicara di depan umum yang digunakan saat praktek adalah metode penyampaian naskah atau manuskrip. Metode ini merupakan metode penyampaian pesan dengan cara dibacakan. Sudah ada 4 (empat) script yang dipersiapkan secara tertulis dan lengkap, ada struktur susunan kalimatnya. Para siswa diminta memilih dan membaca script tersebut, tetapi harus menyampaikan salam pembuka secara lisan, dan juga menjaga gestur tubuh secara nonverbal agar pesan bisa sampai dengan efektif. Kelemahan dari metode ini adalah tidak bisa menghindari bahwa pembicaraan menjadi monoton karena ada kesan membaca naskah, tetapi kekuatannya adalah tidak terjadi pengulangan karena materi sudah lengkap, dan metode ini cocok untuk pembicara 
pemula(Gani, Astuti, Kusumalestari, 2020, h. 10).

Di tengah keterbatasan komunikasi, antusias siswa, bahkan guru untuk belajar ketrampilan berbicara di depan umum sangat tinggi. Walau pada saat sesi awal, sulit membuat siswa untuk berani tampil di depan, karena alasan tidak sanggup, tidak percaya diri, tetapi begitu satu orang berhasil maju maka menyemangati yang lain untuk tertarik mencoba. Metode ini dinilai cukup berhasil karena siswa berhasil menyerap informasi dan mendapatkan ketrampilan dasar ketrampilan berbicara di depan umum. Kelanjutan dari kegiatan ini adalah adanya keinginan pihak sekolah untuk mengadakan sesi pelatihan bagi guru-guru agar bisa mendampingi dan memberikan pengajaran kepada siswa untuk terampil berbicara di depan umum.

\section{HASIL DAN PEMBAHASAN}

Salah satu definisi dasar dari berbicara di depan umum adalah percakapan yang diperluas (Wood, 2013). Ini membutuhkan ketrampilan yang efektif dalam interaksi antar satu orang dengan kelompok orang dalam situasi berbicara di depan umum. Secara umum berbicara di depan umum yang baik adalah tidak terlalu formal atau kaku, dan gaya berbicara perlu menggunakan standarisasi sesuai situasi publik yang dihadapi. Salah satu model komunikasi yang bisa digunakan pada situasi berbicara di depan umum adalah model komunikasi Laswell yang dikutip pada Littlejohn \& Foss (2017), "Who says What, in Which channel, to Whom, with What effect?". Ini merupakan model komunikasi dimana hanya terjadi proses komunikasi minimal satu arah. Ada dua ciri khusus dalam komunikasi publik seperti tanggungjawab pembicara adalah untuk merencanakan dan mempersiapkan materi, interaksi secara langsung hanya sedikit, dan pendengar tetap bisa berpartisipasi dengan cara nonverbal seperti bertepuk tangan atau menganggukkan kepala. Salah satu situasi publik adalah lingkungan di dalam sekolah, dan siswa-siswa di sekolah tersebut juga sesekali perlu melakukan presentasi di depan kelas atau juga di publik sekolah saat pertemuan besar, lomba, dan hal lain yang tentu membutuhkan ketrampilan berbicara di depan publik.

Secara sederhana, berbicara di depan umum (public speaking) dapat didefinisikan sebagai proses berbicara kepada sekelompok orang dengan tujuan untuk memberi informasi, mempengaruhi atau persuasi dan menghibur. Secara sederhana, definisi dari public speaking menurut Gani, Astuti, Kusumalestari, (2020, h. 10) adalah tata cara melakukan aktivitas berbicara di depan umum, sesuai dengan sistematika, runut, dan terencana untuk mencapai tujuan tertentu. Kegiatan berbicara di depan umum ini menjadi penting karena bisa memberikan informasi untuk mengurangi ketidaktahuan, menjelaskan peristiwa atau keadaan sehingga mudah dipahami, sampai pada menyampaikan satu ide atau gagasan untuk menyelesaikan sebuah permasalahan. Kemampuan berbicara di depan umum ini sangat diperlukan dalam berbagai konteks baik dalam kepemimpinan, organisasi, keagamaan, bisnis, dan juga pendidikan. Kebutuhan akan ketrampilan berbicara di depan umum juga dirasakan di sekolah-sekolah. Bukan hanya mendukung kemampuan siswa berprestasi secara akademik tetapi juga membantu siswa mengembangkan kemampuan diri pada bidang lain. Bahkan kemampuan berbicara di depan umum ini juga membantu para siswa sekolah untuk meningkatkan kualitas diri, memupuk keberanian dan mengasah kemampuan.

Salah satu hal yang menghambat kemampuan untuk berbicara di depan umum adalah rasa tidak percaya diri. Untuk mengembangkan rasa percaya diri maka ada beberapa tip yang dikemukakan oleh Maggie Erye (2017) adalah 
(1) Percaya diri, (2) Berbagi kisah-kisah, (3) Rencanakan dan lakukan persiapan, (4) lebih menghormati diri sendiri, (5) Mengenang memori, (6) Menguasai pesan utama, (7) Berlatih, (8) Pemanasan, (9) Bersikap positif, (10) Kuasai materi. Saat sesi materi pelatihan berbicara di depan umum, maka siswa diminta untuk mengembangkan percaya diri, yaitu menumbuhkan pemikiran bahwa setiap siswa itu unik, berbeda satu dengan yang lain, sehingga perlu dibangun kepercayaan pada diri sendiri karena dengan hal tersebut bisa membuat orang lain juga akan percaya pada apa yang kita sampaikan. Untuk memudahkan topik, siswa bisa memulai dengan berbagi kisah-kisah sehingga script yang dibuat pun berdasarkan pengalaman para siswa terkait sekolah, belajar di masa pandemi, hubungan dengan orang tua, hubungan dengan guru. Selain itu sebelum sesi praktek, siswa diminta untuk melakukan persiapan. Sebagai salah satu cara menghormati diri sendiri, pada struktur awal dasar berbicara di depan umum, siswa dituntut berani menyebutkan nama lengkap dan nama panggilannya dengan lantang, ini bisa membantu siswa lebih menghargai nama pemberian orang tua, dan sosok diri sendiri sesuai dengan nama tersebut. Pada poin mengenang memori, saat ilustrasi sebagai jembatan menuju topik yang hendak dibawakan, siswa bisa memberikan kisah terkait masa kecil, hubungan dengan orang tua, pesan orang tua dll, menggugah memori siswa. Kemudian saat masuk deskripsi maka siswa harus mampu menarik kesimpulan pesan utama apa yang hendak disampaikan. Kelemahannya pada sesi pelatihan adalah karena keterbatasan waktu maka siswa kurang mendapatkan kesempatan berlatih terutama melatih pernafasan agar saat berbicara di depan umum tidak terlalu cepat. Tapi karena semangat dan kemampuan siswa untuk menguasai materi dan berpikir positif berhasil dibangun sehingga bisa tampil dengan percaya diri yang baik. Saat siswa berhasil membangun kepercayaan diri, maka konsep dirinya bisa berkembang menjadi pribadi yang lebih baik dan lebih positif serta menghargai setiap kelebihan dan kekurangan yang dimiliki. Konsep diri adalah pemahaman tentang diri sendiri yang timbul akibat interaksi dengan orang lain, berupa pandangan dan perasaan tentang diri kita, bisa bersifat psikologis, sosial, dan fisis (Rakhmat, 2017). Saat kepercayaan diri berhasil dibangun, maka konsep diri bisa lebih positif sehingga memudahkan untuk membangun interaksi dengan orang lain termasuk pada publik.

Saat konsep diri sudah positif, kepercayaan diri berhasil dibangun, maka kekhawatiran saat berbicara di depan umum adalah munculnya kecemasan atau biasa disebut sebagai demam panggung. Definisi "demam panggung" adalah ketakutan yang tiba-tiba datang sangat luar biasa sehingga membuat kita seperti kehilangan ingatan (Eyre, 2017, h. 22). Sehingga walaupun sudah persiapan dan perencanaan materi, karena demam panggung memicu reaksi kimia di otak, sehingga mempengaruhi ingatan kita. Hal ini terjadi pada banyak orang ketika berbicara di depan umum. Kekhawatiran komunikasi di depan publik dengan munculnya rasa cemas merupakan satu hal yang wajar saat kita perlu berbicara di depan audien dalam jumlah besar. Namun ada satu fakta bahwa munculnya sedikit kecemasan maka akan membawa pengaruh pada penampilan yang lebih baik (Brent \& Stewart, 2014) karena adanya dorongan untuk mengerahkan kemampuan memberikan yang terbaik. Saat gangguan kecemasan bisa dikendalikan maka hal itu sangat dibutuhkan untuk sebuah penampilan yang efektif.

Menurut Brent \& Stewart (2014) ada beberapa teknik untuk mengendalikan kecemasan saat berbicara di depan umum yaitu yang pertama adalah Sikap, yaitu mengembangkan sikap bahwa setiap kesempatan 
untuk berkomunikasi di depan umum merupakan sebuah tantangan untuk menyampaikan pesan kepada audien dalam jumlah besar, dan tidak dianggap sebagai hambatan yang tidak dapat diatasi. Selama pelatihan, para siswa ditantang untuk berani berbicara karena ini dibutuhkan saat mereka bersekolah. Para siswa tidak bisa menghindar terus menerus dari sikap yang diam saat ditanya atau mendadak menghindar untuk presentasi didepan kelas. Hal itu tidak bisa dihindari karena merupakan hal yang wajar terjadi dalam proses belajar mengajar. Yang kedua adalah pengalaman, semakin berpengalaman seseorang untuk berbicara di depan umum, maka semakin mudah menghadapi situasi berikutnya. Ini berlaku bagi siswa-siswa yang sudah mau diajak untuk praktek berbicara di depan umum dengan membacakan materi, karena jika sudah berada atau dipaksa pada situasi tersebut, untuk selanjutnya tinggal meningkatkan pengalaman sehingga kemampuan berbicara di depan umum makin terasah.

Dan hal penting yang terus diulang adalah persiapan, jangan pernah mencoba langsung terbang sepanjang kesempatan untuk berbicara di depan umum, sekalipun sebuah pidato yang tampak spontan, perlu dipikirkan secara mendalam sebelumnya. Jadi jika tanpa persiapan sama sekali, sulit bagi kita untuk mengkoreksi atau memperbaiki penampilan saat berbicara di depan umum. Sehingga siswa diberikan kemampuan dasar untuk menyiapkan materi terdiri dari perkenalan diri (introduksi), deskripsi, dan penutup seperti pada terlihat pada gambar,

Gambar : Teknik Dasar Naskah Public Speaking

Sumber : Carnegie \& Berg (2013) 
dalam membantu mengelola kecemasan saat berbicara di depan umum, seperti energi tambahan yang membuat diri semakin percaya diri, misalnya melakukan gerakan tangan untuk mendukung komunikasi verbal atau kata-kata yang kita sampaikan. Tetapi siswa juga diingatkan agar tidak terlalu banyak menggerakkan tangan yang menggangu. Selain itu biasanya karena kecemasan, ada kecenderungan kita untuk banyak menggerakkan badan atau kaki kita, ini sebaiknya harus dikendalikan dan dihindari. Berbicara di depan orang banyak biasanya jika terlalu banyak menggerakkan kaki atau berjalan ke sana kemari malah akan membuat audien kesulitan menangkap isi pesan, dan menjadikan gerakan kita menggangu. Gestur yang perlu diperhatikan adalah sikap berdiri tidak tegak kaku, tapi bisa lebih santai supaya aliran udara bisa keluar dengan baik. Karena salah satu cara untuk mengendalikan kecemasan adalah menarik nafas panjang sebelum memulai pembicaraan.

Pada sesi praktek, siswa juga diingatkan bahwa terkadang kecemasan yang dialami tidak akan diperhatikan oleh audien. Jika ada tandatanda kecemasan yang terlihat adalah suara yang sedikit bergetar, atau tangan yang gemetar, keringat dingin yang mengalir, walaupun ini terlihat tapi karena merupakan sesuatu yang wajar, maka tidak akan menjadi fokus perhatian audien. Sehingga saat mengalami hal tersebut pada bagian awal, maka kita bisa mengendalikannya dengan menarik nafas kembali, dan membuat diri makin rileks jangan fokus pada kritikan audien, karena sebetulnya mereka juga akan mengalami situasi yang sama karena itu hal wajar. Audien tidak akan mengkritik tetapi justru empati pada kondisi kita. Untuk sesi praktek, agar segala kecemasan siswa saat praktek berkurang, maka audien saat itu diingatkan untuk memberikan tepuk tangan saat yang bersangkutan justru tersendat dalam berbicara sebagai salah satu bentuk apresiasi dan semangat agar siswa mampu menyelesaikan presentasinya dengan baik.

Teknik lain dalam mengendalikan kecemasan adalah berusaha berbicara kepada audien seperti layaknya berbicara dengan seseorang bukan dengan sekelompok orang atau di keramaian. Kecemasan komunikasi ringan sering kali dapat diatasi dengan mengarahkan pesan kepada seseorang diantara anggota audien. Bicara secara langsung kepada beberapa orang hanya membuat situasi komunikasi publik seolah menjadi komunikasi interpersonal. Lebih mudah untuk berpikir mengenai seseorang berserta opininya dalam sebuah audien, dibandingkan mencoba untuk menyapa kelompok audien sebagai satu kesatuan. Membangun kontak mata dengan individu di antara audien sering dapat menolong menyembuhkan kecemasan komunikasi. Banyak orang menjadi cemas ketika berbicara kepada sebuah kelompok, tapi kecemasan komunikasi mereka menjadi berkurang ketika mereka memulai untuk berbicara kepada individu-individu tertentu dalam audien. Salah satu trik yang diberikan kepada siswa, saat menjalin kontak mata hanya pada satu individu, dan supaya tidak terlihat oleh audien lain maka seolah membuat kontak mata kepada keseluruhan dengan memberikan arah pandangan mata di atas alis mata atau area dahi. Ini bisa ditangkap audien sebagai sedang membangun atau menjalin kontak mata dengan keseluruhan yang hadir. Hal ini bisa mengurangi rasa cemas karena tidak perlu menatap mata setiap orang yang sudah pasti mengarah kepada pembicara atau siapa yang berbicara di depan umum karena ini merupakan fokus perhatian.

Hal terakhir sebagai teknik mengendalikan kecemasan adalah membangun kesadaran bahwa audien adalah ingin bersahabat dan menginginkan kesuksesan pembicara, menangkap informasi yang disampaikan juga. 
Kebanyakan audien terdiri dari individuindividu yang memang membutuhkan informasi yang disampaikan oleh pembicara, dengan tujuan bisa menyelesaikan tugas dengan baik. Selama kita menyampaikan informasi yang tepat maka audien yang merespon dengan positif. Jika kita sudah mempersiapkan diri dengan baik maka materi kita akan sampai dengan baik dan bermanfaat bagi audien.

\section{KESIMPULAN}

Dalam setiap situasi, dalam berbagai keadaan lainnya setiap hari, proses komunikasi adalah yang benar-benar mendasar. Tidak ada kegiatan yang lebih mendasar untuk kehidupan kita secara pribadi, sosial, atau professional kecuali komunikasi. Komunikasi sangat penting yang kadang tanpa kita sadari bahkan sama pentingnya dengan bernafas. Namun jika komunikasi itu sifatnya alamiah seperti halnya bernafas, mengapa perlu mempertimbangkan dan mempelajarinya? Jawabannya adalah bahwa ada sejumlah keputusan yang mesti dibuat dengan menggunakan proses komunikasi dan cara kita berpikir tentang dan bereaksi terhadap situasi dan orang. Termasuk cara kita bertindak dan berhubungan dengan orang lain.

Kesadaran bahwa komunikasi adalah proses yang mendasar, mau tidak mau menyiratkan bahwa hal itu mudah dipahami dan dikendalikan. Sebaliknya, komunikasi itu sangat kompleks dan memiliki banyak bentuk. Banyak contohnya dalam kehidupan pribadi,

\section{UCAPAN TERIMA KASIH}

Segala Puji dan Kemuliaan serta ucapan terimakasih ditujukan bagi Tuhan yang telah memampukan untuk menyelesaikan proses PKM ini. Secara khusus, ucapan terimakasih ditujukan kepada :

1. Yayasan Pniel Namo Rambe, Deli Serdang, Sumatera Utara. keluarga, masyarakat dan professional (Brent \& Stewart, 2014). Perlu ketrampilan agar menjadi lebih berhasil dalam situasi komunikasi yang kompleks, dengan tantangan pada kehidupan kita sebagai pribadi dalam interaksi dengan keluarga, teman, dan masyarakat. Salah satu yang penting dipelajari adalah kemampuan berkomunikasi di depan umum atau berbicara di depan umum. Kegiatan pengabdian masyarakat lewat pelatihan berbicara di depan umum yang dilaksanakan di SMP dan SMA Pniel, Deli Serdang, telah berhasil memberikan ketrampilan dasar berbicara di depan umum. Tujuan dari pelatihan ini sudah tercapai dengan membentuk siswa untuk lebih percaya diri, mampu berbicara terstruktur, dan kemampuan mendengar. Pada sesi sharing di bagian akhir sesi pelatihan, beberapa siswa menyampaikan sudah tidak takut untuk berbicara di depan umum, dan bisa aktif di kelas untuk belajar. Siswa juga menyampaikan rasa senangnya karena bisa belajar sesuatu yang baru, mengasah ketrampilan, dengan keterbatasan system pembelajaran harus secara online karena pandemi Covid 19. Siswa menjadi lebih bersemangat dan memiliki harapan bisa melewati masa pandemi dengan belajar giat. Sementara kelanjutan dari kegiatan pengabdian masyarakat ini adalah merealisasikan permintaan dari sekolah untuk mengadakan pelatihan bagi guru-guru sekolah ketrampilan berbicara di depan umum.

2. Ibu Rose Tarigan, Dosen Ilmu Komunikasi FISIP UPH, sebagai ketua pelaksana kegiatan PKM, dan teman dalam topik yang berbeda dalam PKM ini.

3. LPPM UPH, Dekan FISIP Naniek N. Setijadi, Kaprodi Ilmu Komunikasi Marsefio Luhukay, seluruh rekan dosen dan administrasi yang membantu dalam melaksanakan PKM ini. 


\section{DAFTAR PUSTAKA}

1. Carnegie, Dale. Esenwein, J. Berg. (2013). The Art of Public Speaking. Start Publishing LLC. New York. USA.

2. CNN Indonesia (2018). Unicef Ungkap Alasan Memilih BTS Pidato di PBB. https://www.cnnindonesia.com/hiburan/201 80925161956-234-333050/unicef-ungkapalasan-memilih-bts-pidato-di-pbb. Diakses pada 25 September 2021.

3. Erye, Maggie. (2017). Speak Easy. Panduan Penting Berbicara di depan Umum. Kompas Gramedia. Jakarta.

4. Gani, Rita. Santi Indra Astuti. Ratri R. Kusumalestari. (2020). Virtual Public Speaking. Simbiosa Rekatama Media.

5. Griffin, A. E. \& Ledbetter, A. \& Sparks, G. G. (2012). A First Look at Communication Theory: $8^{\text {th }}$ Ed. New York: McGraw Hill.

6. Littlejohn, S. W. \& Foss. A. K. (2017). Theories of Human Communication:1 $11^{\text {th }}$ Ed. California: Sage Publisher.

7. Rakhmat, Jalaludin. (2017). Psikologi Komunikasi. Rosda Karya. Bandung.

8. Ruben, Brent.D. Lea P. Stewart. (2014). Komunikasi dan Perilaku Manusia. Penerjemah Ibnu Hamad. Rajawali Pers. Jakarta.

9. UNICEF. BTS Speech at the United Nations. https://www.youtube.com/watch?v=oTe4fbBEKg. Diakses pada 25 September 2021.

10. West, R. \& Turner, H. L. (2017). Introducing Communication Theory Analysis and Application: $6^{\text {td }}$ Ed. New York: McGraw Hill.

11. Woods, Julia. T. (2014). Communication Mosaics. An Introduction to the field of Communication. Sixth Edition. Cengage Learning. Wadsworth. USA.

lembaga/institusi yang telah memberikan kontribusi dalam pelaksanaan kegiatan.

\section{REFERENSI}

Referensi yang dimuat hanya yang disitasi dalam makalah, tidak kurang dari 10 dan diurutkan sesuai abjad. Acuan harus relevan, mutakhir, dan $50 \%$ adalah acuan primer (jurnal terakreditasi, jurnal internasional, tesis, disertasi). Kemutakhiran acuan harus 10 tahun dengan jumlah minimal 70 persen dari daftar referensi. Penulis tidak diperkenankan mengacu pada wikipedia dan halaman blog

Kutipan menggunakan standar format penulisan internasional APA style. Seluruh kutipan menggunakan format bodynote/runningnote. Tidak diperkenankan menggunakan footnote dan atau endnote.

Berikut beberapa contoh cara penulisan referensi.

Huang, X., \& Xie, Y. M. (2010). Evolutionary Topology Optimization of Contimuum Structures: Methods and Applications. Chichester: John Wiley and Sons, Ltd. Publication.

Nayani ZS, Hendre PC. (2015). Comparision and Correlation of Pap Smear with Colposcopy and Histopathiology in Evaluation of Cervix. Journal of Evolution of Medical and Dental Sciences, 4(53): 9236 - 9247.

Asosiasi Pengguna Jasa Internet Indonesia (2016). Penetrasi dan Perilaku Pengguna Internet Indonesia, Survey 2016. 